\begin{tabular}{|c|c|c|c|}
\hline \multicolumn{4}{|c|}{ HeLium. } \\
\hline 11220 & Sun. & & Star or Nebula. \\
\hline $\left.\begin{array}{l}3889 \\
3188 \\
2945 \\
2829 \\
2764 \\
2723 \\
2696 \\
2677\end{array}\right\}$ * & $\mathrm{C}$ & $\mathrm{E}$ & N. III. $\gamma$ \\
\hline $\left.\begin{array}{l}5876 \\
4472 \\
4026 \\
3820 \\
3705 \\
3634 \\
3587 \\
3555 \\
3513 \\
3499 \\
3488 \\
3479 \\
3472 \\
3466 \\
3461\end{array}\right) *$ & $\begin{array}{lr}\text { C } & 100 \\
\mathrm{C} & 100 \\
\mathrm{C} & 25\end{array}$ & $\begin{array}{l}\mathrm{E} \\
\mathrm{E} \\
\mathrm{E} \\
\mathrm{E}\end{array}$ & a Cygni \\
\hline 7066 & C 100 & & \\
\hline $\begin{array}{l}4713 \\
4121 \\
\end{array}$ & C 2 & E & N. $\alpha$ Cygni \\
\hline $\begin{array}{l}3868 \\
3777 \\
3652 \\
3599 \\
3567 \\
3537 \\
3517 \\
3503 \\
3491 \\
3482\end{array}$ & & $\stackrel{?}{\mathrm{E}}$ & Bellatrix \\
\hline
\end{tabular}

GaS X.

\begin{tabular}{|c|c|c|}
\hline & Sun. & Star or Nebula. \\
\hline $\begin{array}{l}5 \text { or } 6 \\
3965 \\
3614 \\
3448\end{array}$ & $\begin{array}{ll}\mathrm{C} 30 \quad \mathrm{E} \\
\\
\\
\stackrel{\mathrm{E}}{?}\end{array}$ & III. $\gamma$ \\
\hline
\end{tabular}

In the tables, under "Sun," C, followed by a number, indicates the frequency as given by Young; $\mathrm{E}$ indicates the lines photographed during the eclipse of 1893 . Under "star or nebula" the references are to the tables given in my memoir on the nebula of Orion (Phil. Trans. vol. clxxxvi. (1895), p. 86 et seq. $\mathrm{N}=$ Nebula of Orion).

Hydrogen, helium, and gas $\mathrm{X}$ are thus proved to be those elements which are, we may say, completely represented in the hottest stars and in the hottest part of the sun that we can get at. Here then, in 1895 , we have abundant confirmation of the views I put forward in 1868 as to the close connection between helium and hydrogen. J. NORMAN LOCKYER.

\title{
RESEARCH IN ZOOLOGY AT OXFORD.
}

THE second volume of the Linacre Reports, which has lately been printed, shows that the zoological laboratory at Oxford continues to be a source of production of many interesting and valuable contributions to knowledge.

In the course of a little more than one year the colleagues and pupils of Prof. Lankester have published a number of memoirs and essays, which, when collected together, form a bulky octavo volume, illustrated by numerous lithographs and woodcuts.

There is, as might be expected, considerable range in the interest and importance of the several items composing the volume, but not one of them could have been omitted without lessening its value to the zoologist. At least four of the memoirs are of such importance that they may be considered to be standard works to which reference must be frequently made in future by naturalists of all nationalities. Of these, perhaps, the most important is Prof. Poulton's memoir on the structure of the hair and bill of the duck-billed Platypus, which contains not only an excellent account of certain histological features of this rare animal, but some extremely suggestive remarks, derived from this research, on the relations of hairs and scales.

Dr. Benham's beautifully illustrated essay on the brain of the interesting Chimpanzee "Sally," which recently lived and died in the Zoological Gardens in London, forms an important chapter in "Man's place in Nature." The careful comparison which Dr. Benham gives of the large and valuable series of anthropoid and human brains which he has examined, makes this memoir one of special interest and importance.

Mr. Bourne's monograph on the post-embryonic development of Fungia gives us, at last, detailed information and good illustrations of a subject which has long interested zoologists.

The description of Prof. Lankester's collection of the species of Amphioxus and the genera allied to it, which has been carefully and ably written by Miss Kirkaldy, forms a memoir which will be welcomed heartily by zoologists in all civilised countries.

The other contributions to this volume are of less importance, :perhaps, than those referred to above, but they are all useful additions to our knowledge of many widely separated branches of zoology, and being carefully written, and the result of work done under excellent advice and guidance, cannot be neglected by those who are specially interested in the branches of zoology of which they treat.

With such a volume of good useful work before us, it is truly lamentable to read in Prof. Lankester's editorial preface of the general indifference prevailing in the governing bodies of the Oxford colleges towards the progress of natural knowledge. The University of Oxford and the colleges together are the possessors of very large endowments for the cultivation of learning in all its branches. No university in the empire is so fortunately 1 "The Linacre Reports." Vol. ii. 
situated, as regards funds, as Oxford is at the present day, and yet the just claims of the most progressive sciences upon her vast resources are persistently neglected, and she remains in the position of a follower rather than a leader in most of the scientific movements of the day.

The efforts that Prof. Lankester has so successfully made to stimulate his pupils to investigate natural things, have been made in spite of, and not as they should have been with the warm support and sympathy of the collegiate systems that prevail in Oxford.

During the past ten years only four fellowships have been awarded to young zoologists of promise by the Oxford colleges. The recipients of this support have each produced valuable work, which has reflected great credit upon themselves and the enlightened action of the colleges to which they belong. Not one of them has joined the ranks of the idle fellows which abound in the old universities of this country. The experiment cannot, therefore, be said to be a failure. It is as a fact the most conspicuous success of any of the college enterprises of the present day. Why then, it may be asked, have not other colleges followed the example that has been set? The answer to this question is to be found in the fact that, in consequence of the unfortunate competition that exists between colleges to swell the ranks of their undergraduates, the income of the endowments is frittered away in the salaries of the hcads, the stewards, the bursars, and the tutors of the pass-men. Whether the time will soon come when a radical alteration will be made in the administration of the college endowments it is difficult to say, but there can be no doubt that the present state of affairs as regards the support of natural science in Oxford is little short of scandalous, and should call for the serious attention of men of influence who have her interests at heart.

Prof. Lankester is to be congratulated on the efforts he has personally made, as shown by the two volumes of "The Linacre Reports," to stimulate research in his own branch of science at Oxford; and it is to be most sincerely hoped that, in a little while, his enterprise will meet with the recognition from the colleges that it deserves.

SYDNEY J. HICKSON.

DEEP SOUNDING IN THE PACIFIC.

A DEEPER spot in the ocean than any yet known has A been recently found by H.M. surveying ship Penguin. Unfortunately the observation was not complete, as a fault in the wire caused it to break when 4900 fathoms had run out without bottom having been reached.

Commander Balfour reports that this occurred in lat. $23^{\circ} 40^{\prime}$ S., long. $175^{\circ} 10^{\prime}$ W., about 60 miles north of a sounding of 4428 fathoms obtained by Captain Aldrich in 1888 . A previous attempt to reach bottom had been foiled by a similar accident to the wire when 4300 fathoms had passed out, and the rising wind and sea prevented any further attempt at the time. As the deepest cast hitherto obtained is one of 4655 fathoms near Japan, it is at any rate certain that the depth at the position named is at least 245 fathoms greater.

It is hoped that before long a more successful attempt to find the actual depth will be made.

September 28 .

W. J. L. WHARTON.

\section{LOUIS PASTEUR.}

$\mathrm{O}^{\mathrm{x}}$ Saturday afternoon, M. Pasteur died at Garches, near St. Cloud, where he had gone for the summer in order to be near Paris, and at the same time to be near the large establishment for the preparation of antitoxic serum.

In 1868 , Pasteur suffered from an attack of paralysis, the result apparently of a cerebral hæmorrhage; but although traces of this paralysis remained, he enjoyed No. I 353 , VOL. 52 ] fairly good health until 1887, when he developed symptoms of heart and kidney disease, probably a recrudescence of the diseases associated with his earlier paralysis. Four years ago he suffered from influenza, which appears to have left further weakness of the heart. Last winter he was unable to do any work, and in fact was confined to bed for several months; but when summer came, he was able to go to his country house at Villeneuve l'Etang, near St. Cloud, where he remained in comparatively good health, though easily fatigued, untıl about three weeks ago, when he seems to have felt that the end was approaching. It is stated that "about three weeks ago he kissed his grandchildren fondly, and pressed each for some time to his breast, sobbing as he did so. On being asked what was the matter, he said "The matter is that I must so soon leave them." He appeared to be no worse at this time, but about a week later symptoms of uramia began to develop, he became comatose, and on Wednesday last the uræmic poisoning became more marked, and by Friday it was evident that there could be only one termination to the illness.

In r89r (NATURE, March 26) we gave a sketch of his life from the pen of Sir James Paget, some features of which may now be repeated. "Louis Pasteur was born on December 27,1822 , at Dôle, in the Jura, where his father, an old soldier who had been decorated on the field of battle, worked hard as a tanner." Father and mother alike seem to have been earnest, thoughtful people, whose one ambition seems to have been to "make a man" of their son.

"In 1825 they removed to Arbois, and as soon as he was old enough to be admitted as a day boy, Pasteur began his studies in the Communal College, and there after the first year or two, he worked hard and gained distinction." He then, in turn, studied, for a year at the college of Besançon and at the École Normale. He was only fourteen when he first applied for admission, but it was not until he had studied for a year that he went in for the examination; and in 1843 it is recorded that he was fourth on the list of successful competitors. At a very early period he devoted special attention to chemistry under Darlay at Besançon, and then under Dumas at the Sorbonne, and Balard at the École Normale. Here, too, in the École Normale, he com. menced that study of molecular physics, especially in relation to the formation of crystals, which led up to his now classical investigation on the isomeric crystals of the tartrates and paratartrates of soda and ammonia. In 1847 he took his degree of Doctor of Science, after which he was appointed Assistant and then Professor of Chemical Physics in the University of Strassburg. In 1854 he was appointed Dean of the Faculty of Sciences at Lille, where he spent three years in organising the new school, and commenced those experiments on fermentation which seemed to follow naturally on his researches on the tartaric acids. He found that certain processes of fermentation were set up by distinct micro-organisms, under the action of which organic salts and even inorganic substances were broken down, and others were formed in their place. Three years later he was appointed Director of Studies in the École Normale in Paris, which office he retained until I867. During this same period he was Professor, first of Geology, then of Physics, and latterly of Chemistry in the École des Beaux Arts. He also held the position of Professor of Chemistry at the Sorbonne.

As early as 1856 , before his recall to Paris, the Royal Society of London awarded to him the Rumford Medal for his researches on the polarisation of light. In I 869 he was made a foreign member of the Royal Society, and in 1874 the Copley Medal was given to him. It is interesting to note in connection with his recent action as regards the Order offered to him by the Emperor William, that, during the bitterness caused by 